\title{
ACACA Gene
}

National Cancer Institute

\section{Source}

National Cancer Institute. ACACA Gene. NCI Thesaurus. Code C103885.

This gene plays a role in the synthesis of long-chain fatty acids. 